\title{
THE EFFECTS OF TWO DIFFERENT PRESERVATION METHODS ON MORPHOLOGICAL CHARACTERISTICS OF THE ALIEN CHANNEL CATFISH Ictalurus punctatus (Rafinesque, 1818) IN EUROPEAN FRESHWATER
}

\author{
Phillip J. Haubrock ${ }^{1,2}$ * , Paride Balzani ${ }^{1}$, Iva Johović ${ }^{1}$, Alberto Francesco Inghilesi ${ }^{1,2}$, Elena \\ Tricarico ${ }^{1}$
}

'Department of Biology, University of Florence, Via Romana 17, 50125 Florence, Italy ${ }^{2}$ NEMO, Nature and Environment Management Operators s.r.I., Piazza M. D’Azeglio 11, 50121 Florence, Italy

*Corresponding Author, Email: phillip.haubrock@hotmail.de

\section{ARTICLE INFO}

Received: 11 January 2018

Received in revised form: 9 March 2018

Accepted: 12 March 2018

Available online: 18 April 2018

\section{Keywords:}

Fish morphology

Freezing

Cooling

Colour

Alteration

\begin{abstract}
Different methods used to store specimens, even for short periods, can notably affect morphometric characteristics such as colour, length and shape. As a consequence, in the case of samples that have to be analysed morphometrically, the right preservation method is crucial. In this study, two comparably easy applicable methods, the effects of freezing and moderate cool storage on morphological traits, were studied on specimens of the scaleless North American channel catfish Ictalurus punctatus, an alien species to European freshwaters of increasing concern. Results revealed that freezing, like preservation with alcohol or formalin, affected the generally considered characteristics (colour, standard length, fork length, total length, shape), while cool storage was shown to preserve most traits without notable alteration, an important difference when studying potentially adapting alien species. Implications are discussed.
\end{abstract}

Haubrock, P.J., Balzani, P., Johović, I., Inghilesi, A.F., Tricarico, E. (2018): The effects of two different preservation methods on morphological characteristics of the alien channel catfish Ictalurus punctatus (Rafinesque, 1818) in European freshwater. Croatian Journal of Fisheries, 76, 80-84. DOI: $10.2478 /$ cjf-2018-0010.

\section{INTRODUCTION}

Biological samples are generally, according to purpose and further use, preserved under varying conditions (Asahida et al., 1996; Gould, 1996; Jawad et al., 2001; Ghaly et al., 2010). For the identification of fish specimens, ichthyologists usually use formalin, alcohol or freezing as a way to preserve morphological characteristics (Ghaly et al., 2010). Storing samples in formalin and alcohol as a long-term measure is reasonable, but short-term storage of large quantities (e.g. transport) can be delicate and is not always the most efficient method. However, the availability, transportation and storage of ice is not always a feasible option. Different short and long-term storage techniques have been shown to affect taxonomically important morphometric characteristics of fish, such as length (e.g. Al-Hassan and Shawafi, 2003). Additionally, when considering the water content ratios of white and red muscles, the effect of storage and preservation method may cause variations between scale-less and scaled fish (Leslie and Moore, 1986). Few studies deal with the 
effect of varying preservation methods on pigmentation and morphometric characteristics in different species of fish (see e.g. Jawad et al., 2001; Neave et al., 2006). This variability in morphology among different preserved species and samples can be due to several factors such as time elapsing until preservation, the applied preservation method, concentration of preservative, preservation duration and temperature, morphological variability among specimens, and species-specific factors (age, size, state, the osmoregulatory activity of the fish at the point of death) (Yeh and Hodson, 1975). As the North American channel catfish Ictalurus punctatus is receiving an increasing scientific attention in Europe as an alien species (Banha et al., 2017; Haubrock et al., 2017) and due to the potential influx of further North American catfish species that are difficult to distinguish by the untrained eye, a preservation method that does not impact morphological characteristics is needed.

The present work aims at investigating the effect of two easy applicable methods, freezing and cooling, on morphological characteristics. These options were chosen as two commonly applied and feasible methods for transporting and storing freshly caught specimens.

\section{MATERIALS AND METHODS}

Specimens of Ictalurus punctatus were collected from the River Arno (Central Italy). Immediately after the capture, morphological characters of all samples (total length, standard length and fork length, body shape and colour) were measured or photographed. Subsequently, specimens were euthanized with a standard gill cut. Twenty samples per preservation method were stored in two batches of ten specimens each. Specimens in the freezing treatment were directly laid on and covered with ice cubes and were then transported to a standard freezer within one hour and frozen at $-20^{\circ} \mathrm{C}$. For the cooling treatment, cooling down without freezing was achieved by transferring specimens into a reefer-container and loosely placing them between cloth-wrapped cold packs. Cold packs were replaced with new replenished packs after eight hours to keep the temperature between 2 and $4^{\circ} \mathrm{C}$. After 96 hours, cooled and frozen specimens were measured again, and measurements were compared. In the case of frozen samples, defrosting was achieved at ambient temperature over a period of $2-4$ hours. Specimens were straightened up and subsequently measured. Measurements from before and after preservation for both methods were analysed using paired t-test (statistic: $\mathrm{t}$ ); changes in length before and after preservation were compared between the two methods using Mann-Whitney test (statistic: $U$ ). The level of significance under which the null hypothesis was rejected was $\alpha=0.05$. Table 1 provides mean values or median values plus standard error or $1^{\circ}-3^{\circ}$ interquartile. SPSS $^{\circledR}$, Statistical Package for Social Science 13.0 for Windows was used for the statistical analyses.

Table 4. Comparisons of changes in Standard- Fork- and Total-Length between frozen and cooled specimens using MannWhitney-U test $[\mathrm{U}]$, and lengths before and after freezing and cooling using paired $t$-tests [t]. For paired $t$-tests, means \pm standard errors and for Mann-Whitney-U Tests medians and $1^{\circ}-3^{\circ}$ interquartiles are reported. Significant values are highlighted in bold.

\begin{tabular}{|c|c|c|c|c|c|c|}
\hline \multicolumn{7}{|c|}{ Cooling vs. Freezing } \\
\hline \multirow{2}{*}{\multicolumn{2}{|c|}{ Parameter }} & $U$ & $\mathbf{n}$ & $\mathbf{p}$ & Freezing & Cooling \\
\hline & & & 20 & & & \\
\hline \multirow{3}{*}{\multicolumn{2}{|c|}{ Change Standard Length $(\mathrm{cm})$}} & & 20 & & & \\
\hline & & 208 & 40 & $<0.01$ & $0.74(0.3-0.98)$ & $0.1(0.0-0.2))$ \\
\hline & & & 20 & & & \\
\hline \multirow{3}{*}{\multicolumn{2}{|c|}{ Change Fork Length $(\mathrm{cm})$}} & & 20 & & & \\
\hline & & 207.5 & 40 & $<0.01$ & $0.64(0.3-0.8)$ & $0.1(0.0-0.18)$ \\
\hline & & & 20 & & & \\
\hline \multirow{2}{*}{\multicolumn{2}{|c|}{ Change Total Length $(\mathrm{cm})$}} & & 20 & & & \\
\hline & & 190 & 40 & $<0.01$ & $0.62(0.3-0.7)$ & $0.1(0.0-0.1)$ \\
\hline \multicolumn{7}{|c|}{ Before and after preservation } \\
\hline \multirow[t]{2}{*}{ Preservation method } & Parameter & $\mathbf{t}$ & df & p & Before & After \\
\hline & Standard Length $(\mathrm{cm})$ & -6.579 & 20 & $<0.01$ & $23.26 \pm 2.47$ & $24.00 \pm 2.56$ \\
\hline \multirow[t]{3}{*}{ Freezing } & Fork Length $(\mathrm{cm})$ & -6.312 & 20 & $<0.01$ & $25.59 \pm 2.70$ & $26.22 \pm 2.79$ \\
\hline & Total Length $(\mathrm{cm})$ & -7.132 & 20 & $<0.01$ & $28.77 \pm 2.80$ & $29.39 \pm 2.88$ \\
\hline & Standard Length $(\mathrm{cm})$ & -5.667 & 20 & $<0.01$ & $26.25 \pm 2.59$ & $26.33 \pm 2.60$ \\
\hline \multirow[t]{2}{*}{ Cooling } & Fork Length $(\mathrm{cm})$ & -5.596 & 20 & $<0.01$ & $28.42 \pm 2.66$ & $28.52 \pm 2.68$ \\
\hline & Total Length $(\mathrm{cm})$ & -5.6270 & 20 & $<0.01$ & $32.40 \pm 2.92$ & $32.50 \pm 2.93$ \\
\hline
\end{tabular}


A

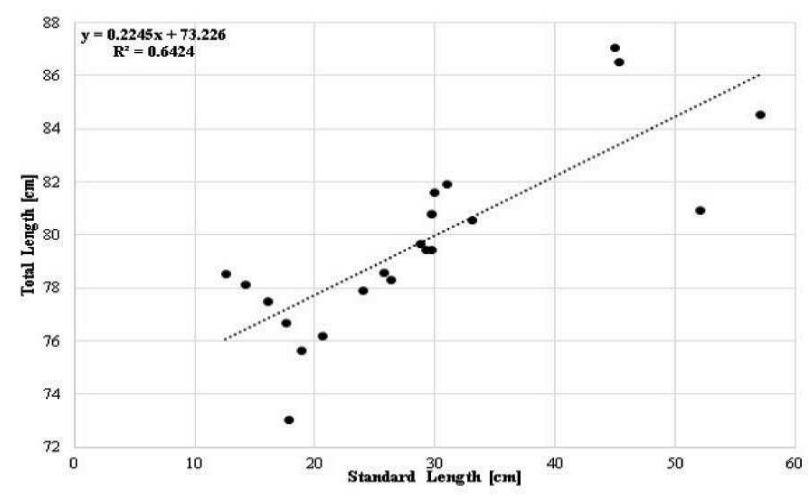

B

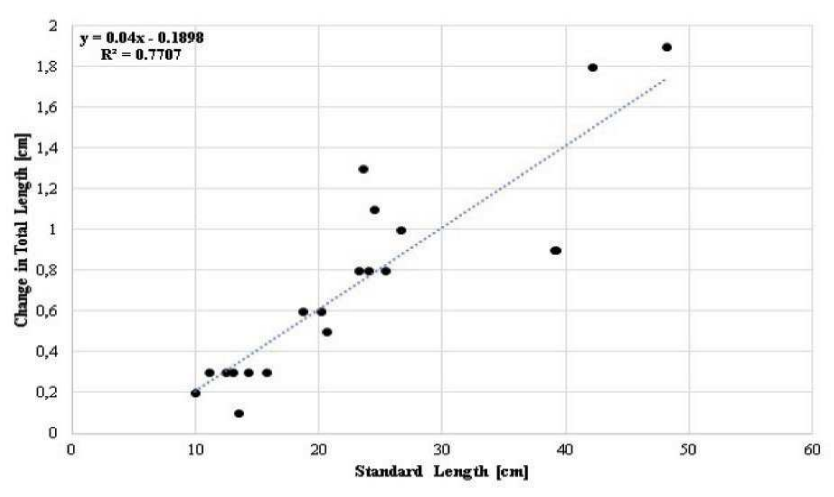

Fig 1. A) Standard length (X-Axis) in relation to total length (Y-Axis) before freezing. B) Standard length (X-Axis) in relation to increase of total length (Y-Axis) after 96 hours of freezing

\section{RESULTS}

Freezing and cooling led to different effects on morphological characters. In the case of freezing, a degradation in colour from goldish-brown to grey-blackish was visible in every case, while the body shape was unaffected overall, except for the belly being less elevated, soft and pliable after defrosting. The standard length of frozen fish increased between 0.1 and $1.9 \mathrm{~cm}(\sim 3.3 \%)$, the distance between standard length and fork length by $0.1-0.4 \mathrm{~cm}$ and total length respectively by $0.1-0.5 \mathrm{~cm}$. Results of statistical analysis are displayed in Table 1.

Additionally, the changes in size of specimens are linked to increases in all length categories (Fig. 1.). Comparably in cooled specimens, the increase in all length measures was between 0 and $0.2 \mathrm{~cm}$, bellies kept their firm shape and, although colour changed, it maintained a lighter tone (including the typical punctuation of $I$. punctatus) (Fig. 2.).

A

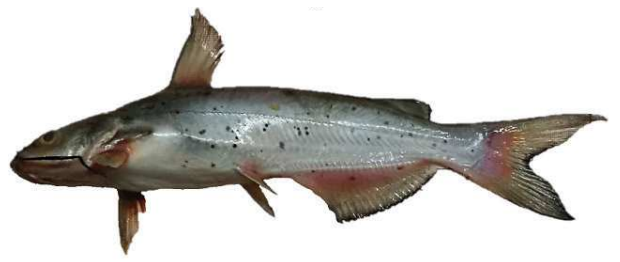

B

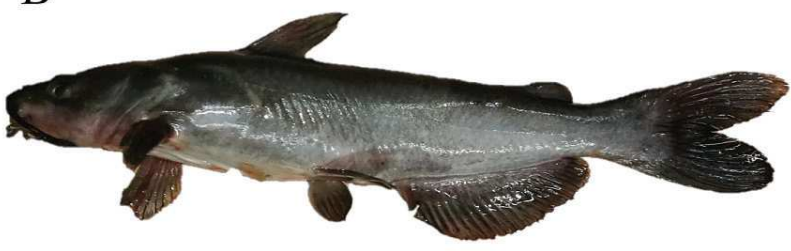

Fig 2. Comparison between a specimen of Ictalurus punctatus after A) 96 hours of cooling and B) 96 hours of freezing

\section{DISCUSSION}

Differences in size, shape or size of morphological characters can be of outmost importance in studies assessing the morphology of a target species (Sayers, 1987; Al-Hassan and Shawafi, 2003). This is crucial when studying similar species with overlapping distributions, such as $I$. punctatus, Ictalurus furcatus and Ameiurus catus. These species can be morphologically variable, as for instance in the case of genetic introgression in $I$. punctatus, causing anal fin ray reduction up to $23 \mathrm{~cm}$, making it morphologically more similar to $A$. catus. Another example might occur in the future when alien species which are genetically compatible and morphologically very similar species with almost identical juvenile life stages, such as $I$. punctatus and $I$. furcatus, hybridize, making morphological distinction crucial. Furthermore, to the best of our knowledge, there are no standard approaches to calculate the size of specimens while alive based on only the size of preserved specimens. There is no evidence of standard correlation factors between living length and preserved length (Yeh and Hodson, 1975). In the present study, both preservation by freezing and by cooling had a significant effect on fish size. However, freezing caused a significantly higher increase compared to cooled specimens. Furthermore, we observed a change in skin colour and pigmentation in frozen specimens, leading to a much darker tone and invisibility of the typical black dots of the species. This pigmentation change has also been similarly observed in rainbow trout (Chen et al., 1984; No and Storebakken, 1991). Conversely, cooling down preserved most traits in a more reliable way. Hossaini et al. (2016) found that, as an alternative to the described cooling and freezing, preservation with alcohol affected colour and body proportion of Zagros toothcarp Aphanius vladykovi. Additionally, Jawad et al. (2001) state there is shrinkage of multiple characteristics caused 
by different concentrations of formalin and alcohol, and also freezing, in sparid-fishes. In contrast, Al-Hassan and Abdullah (1982) observed the opposite, a slight increase in preserved specimen sizes. Although the impact of preservation using alcohol and formalin has not been the target of this study, differing results and the most often observed shrinkage in length can be explained by varying chemical concentrations in the body (e.g. a gradient in the tail), genetically based differences in white to red muscle ratios and variable fluid content (Leslie and Moore, 1986; Hossaini et al., 2016). Hence, different preservatives may influence characteristics differently and thus, while alcohol may damage proteins and therefore the tissue, formalin will negatively affect the colour while sustaining colour pattern. Therefore, a standardized and repeatable preservation is of interest for the correct identification and analysis of morphology. Subsequently, it can be stated that the applicability of preservation with alcohol, formalin and freezing can be considered as more difficult to apply considering the hardship of transporting a sufficiently sized container and proper amounts of preservative when dealing with multiple bigger sized specimens. We therefore suggest that morphometric measures on channel catfish should be taken directly on fresh or cooled specimens, while the use of frozen and defrosted fishes should be avoided for potential misidentification of species.

\section{ACKNOWLEDGEMENTS}

This project has received funding from the European Union's Horizon 2020 research and innovation programme under the project Marie Sklodowska-Curie Aquainvad-ED (H2020-MSCA-ITN-2014-ETN-642197).

\section{SAŽETAK}

\section{UTJECAJ DVIJE RAZLIČITE METODE KONZERVACIJE NA MORFOLOŠKE KARAKTERISTIKE KANALSKOG SOMA Ictalurus punctatus (Rafinesque, 1818) U EUROPSKOM VODOTOKU}

Različite metode koje se koriste za pohranu uzoraka, čak i u kraćim vremenskim razmacima, mogu uvelike utjecati na morfometrijske osobitosti kao što su boja, duljina i oblik uzorka. Kao posljedica, u slučaju da uzorci moraju biti analizirani morfometrijski, odabir odgovarajuće metode konzervacije/očuvanja uzorka je ključna. U ovom istraživanju su uspoređeni učinci, dvije podjednako lako primjenjive metode očuvanja, smrzavanja i umjereno svježeg skladištenja na morfološka obilježja sjevernoameričkog kanalskog soma Ictalurus punctatus, kao strane vrste prisutne u Europskim kopnenim vodama. Rezultati su ukazali da je smrzavanje, kao i konzervacija alkoholom ili formalinom, utjecalo na općenite karakteristike uzorka (boja, standardna, ukupna i duljina ribe do vilice te oblik), dok je umjereno svježe skladištenje indiciralo očuvanje većine osobina uzorka bez istaknutih promjena, što je važna razlika pri proučavanju potencijalno prilagodljivih stranih vrsta riba. $U$ radu su razmatrane implikacije.

Ključne riječi: Morfologija ribe, smrzavanje, hlađenje, boja, promjena

\section{REFERENCES}

Al-Hassan, L.A.J., Abdullah, J.N. (1992): The effect of formalin and freezing on some body proportions of Barbus luteus. Pakistan Journal of Zoology, 24, 4, 353-354.

Asahida, T., Kobayashi, T., Saitoh, K., Nakayama, I. (1996): Tissue preservation and total DNA extraction form fish stored at ambient temperature using buffers containing high concentration of urea. Fisheries Science, 62, 5, 727-730.

Banha, F., Veríssimo, A., Ribeiro, F., Anastácio, P. M. (2017): Forensic reconstruction of Ictalurus punctatus invasion routes using on-line fishermen records. Knowledge and Management of Aquatic Ecosystems, 56, 418.

Chen, H.M., Meyers, S.P., Hardy, R.W., Biede, S.L. (1984): Colour stability of astaxanthin pigmented rainbow trout under various packaging conditions. Journal of Food Science, 49, 5, 1337-1340.

Ghaly, A.E., Dave, D., Budge, S., Brooks, M.S. (2010): Fish spoilage mechanisms and preservation techniques. American Journal of Applied Sciences, 7, 7, 859.

Gould, G.W. (1996): Methods for preservation and extension of shelf life. International journal of food microbiology, 33, 1, 51-64.

Haubrock, P. J., Johovic, I., Balzani, P., Inghilesi, A. F., Nocita, A., Tricarico, E. (2017): Assessing the impacts of the invasive Channel catfish Ictalurus punctatus in central Italy. 20th International Conference of Aquatic Species. October 22-26 Fort Lauderdale, US. 144.

Hossaini, S.A., Vajargah, M.F., Sattari, M. (2016): The effect of preservation in alcohol on the morphological characters of the Zagros tooth-carp, Aphanius vladykovi Coad. Journal of Environmental Treatment Techniques, 4, 4, 118-120.

Jawad, L.A., Toumi, F.F.E., Barasi, H.M. E., Silini, O.A.E. (2001): The effect of preservatives and freezing on the morphological characters of two sparid fishes. Indian Journal of Fisheries, 48, 4, 423-426.

Jawad, L.A. (2003): The effect of formalin, alcohol and freezing on some body proportions of Alepesdjeddaba (Pisces: Carangidae) collected from the Red Sea coast of Yemen. Revista de biología marina y oceanografía, 38, 2, 77-80.

Jayaram, K.C. (2002): Fundamentals of fish taxonomy, Narendra Publishing House. 
Leslie, J.K., Hodson, R.G. (1975): Changes in lengths of fixed and preserved young freshwater fish. Canadian Journal of Fishery and Aquatic Science, 43, 1079-1081.

Neve, F.B., Mandrak, N.E., Docker, M.F., Noakes, D.L. (2006): Effects of preservation on pigmentation and length measurements in larval lampreys. Journal of Fish Biology, 68, 4, 991-1001.

No, H.K., Storebakken, T. (1991): Colour stability of rainbow trout fillets during frozen storage. Journal of Food Science, 56, 4, 969-972.

Sayer, R.E. (1987): Effects of freezing in and out of water on length and weight of Lake Michigan bloaters. North American Journal of Fishery Management, 7, 299-301.

Yeh, C.F., Hodson, R.G. (1975): Effects of formalin on length and weight of bluegill and white crappie from Lake Nasworthy, Texas. Southwest Naturalist, 20, 315-322. 